\title{
Review \\ Potential Clinical Benefits of TDM of Antimicrobials in Japan
}

\author{
Fumiya Ebihara, Yukihiro Hamada *, Takumi Maruyama and Toshimi Kimura
}

\begin{abstract}
Department of Pharmacy, Tokyo Women's Medical University Hospital, Tokyo 162-8666, Japan; ebihara.fumiya@twmu.ac.jp (F.E.); maruyama.takumi@twmu.ac.jp (T.M.); kimura.toshimi@twmu.ac.jp (T.K.)

* Correspondence: hamada.yukihiro@twmu.ac.jp
\end{abstract}

\begin{abstract}
Under the Japanese health insurance system, medicines undergoing therapeutic drug monitoring (TDM) can be billed for medical fees if they meet the specified requirements. In Japan, TDM of vancomycin, teicoplanin, aminoglycosides, and voriconazole, which are used for the treatment of infectious diseases, is common practice. This means the levels of antimicrobial agents are measured in-house using chromatography. This review describes personalized medicine based on the use of chromatography as a result of the current situation in Japan.
\end{abstract}

Keywords: HPLC; TDM; ceftriaxone; daptomycin; linezolid

\section{Introduction}

In Japan, insurance claims based on therapeutic drug monitoring (TDM) became possible for lithium carbonate in the treatment of manic depression in 1980, followed by antiepileptic drugs and digitalis the following year. Since then, the therapeutic benefits of TDM have been confirmed, the number of drugs covered has gradually expanded, and insurance billing rates have increased. When the blood concentration of the administered drug is measured and the dosage precisely controlled based on the results, the associated costs can be calculated and billed only once in a calendar month.

The insurance billing fee includes the costs for measuring the blood drug concentration, drawing blood for this measurement, and administering of the dosage based on the results, and the cost of measuring the blood concentration more than once in a single month cannot be calculated separately. In addition, the blood concentration of the drug and the main points of the treatment plan should be detailed in the medical record.

In the 1980s and 1990s, high-performance liquid chromatography (HPLC) played a significant role in the analysis of drug concentrations in blood. However, with the spread of simple automated analyzers based on ligand-binding assays and the promotion of outsourcing to clinical laboratories, the number of medical institutions with HPLC capability has decreased [1]. In the area of clinical toxicology, precision analytical equipment was installed in emergency departments in 1998 with support from the Ministry of Health, Labor and Welfare, but most of the equipment are systems for high-performance liquid or gas chromatography coupled with mass spectrometer detectors; not many facilities use HPLC with UV-visible detectors as their main equipment [2,3].

Focusing on drugs for infectious diseases, the only drugs that can be billed to insurance in Japan are vancomycin, teicoplanin, aminoglycoside antibiotics, and voriconazole. In some facilities, the blood and tissue concentrations of other drugs are measured by HPLC and applied to treatment, which is necessary for personalized medicine. In this paper, we focus on antimicrobial agents that are not covered by insurance and introduce the clinical significance of TDM and methods for measuring blood concentrations with examples from our own experience. 


\section{TDM of Ceftriaxone}

\subsection{Characteristics of Ceftriaxone and Significance of TDM}

Ceftriaxone (CTRX) is a third-generation cephalosporin that has a broad antibacterial spectrum, good tissue migration, and a longer half-life than other cephalosporins, allowing once-daily administration. CTRX has been used for a variety of indications and has many opportunities for use [4]. In addition, dose adjustment is not necessary for patients with impaired renal function [5]. Patel et al. reported that adjusting the dosage regimen of ceftriaxone for patients with impaired renal function should not be necessary when the daily dosage is $2 \mathrm{~g}$ or lower [6]. Antibiotic-associated encephalopathy (AAE) is a known side effect of cephalosporins. AAE is classified into three major categories: type I for cephalosporins and penicillins, type II for quinolones and macrolides, and type III for metronidazole; type I is said to be free of epileptic waves [7]. In particular, there have been many reports on AAE with cefepime (CFPM), a fourth-generation cephalosporin drug, including reports on the intoxication zone of blood levels responsible for AAE [8-10]. There are also scattered reports of AAE caused by CTRX, and according to an adverse drug reaction database study in France, serious CNS adverse effects caused by CTRX and CFPM were reported to be similar [11]. AAE with CTRX has been reported more frequently in the elderly and patients with chronic kidney disease and is more likely to occur when high doses are given and blood and cerebrospinal fluid (CSF) concentrations are high [12-14].

In a recent report, Lacroix et al. [15] used the French pharmacovigilance database to analyze records of CNS adverse events due to CTRX that were recorded as occurring in 1995-2017. A total of 152 serious adverse drug reactions (ADRs) were analyzed: 112 resulted in hospitalization or prolonged hospitalization $(73.7 \%), 12$ resulted in death $(7.9 \%)$, and 16 were life-threatening. The median age was 74.5 years, and the median rate of creatinine clearance was $35 \mathrm{~mL} / \mathrm{min}$. The median time of onset was 4 days; the mean daily dose was $1.7 \mathrm{~g}$, with three patients receiving doses exceeding the maximum recommended dose; and plasma ceftriaxone levels were recorded in 19 patients (12.5\%), with eight patients exceeding the threshold for toxicity $(>100 \mu \mathrm{g} / \mathrm{mL})$. In addition, electroencephalography performed on 50 patients (32.9\%) showed abnormalities in 37 (74\%).

Although the frequency of CTRX-related encephalopathy in Japan is not clear, it has been reported that the sales volume of third-generation cephalosporins is about six times higher than that of fourth-generation cephalosporins [16], and caution is required.

\subsection{Report on the Measurement of Blood Levels and CSF of CTRX in Japan}

In Japan, we searched for clinically applied studies on CTRX that are not generally clinically measured. As a results, we present reports on the measurement of CTRX concentrations in cerebrospinal fluid by HPLC-UV in Japan.

Kotani et al. [17] measured CTRX concentrations in CSF samples collected from peritoneal dialysis patients diagnosed with CTRX-induced encephalopathy (CIE) using an HPLC-UV system to investigate whether high CTRX concentrations in CSF are associated with CIE. Their study used an octadecyl silica (ODS) column, methanol, and a mobile phase of mixed solution $(25: 75, v / v)$ in $10 \mathrm{mM}$ phosphate to accurately analyze CSF samples from CIE patients; the detection wavelength was $280 \mathrm{~nm}$. Based on the current HPLCUV capability, a linear range of $0.1-100 \mu \mathrm{g} / \mathrm{mL}(\mathrm{r}=0.999)$ was obtained. In a recovery study using a blank sample of human CSF and a control serum supplemented with CTRX, recovery of CTRX was $\geq 95.3 \%$, and the RSD was $<5.8 \%(n=3)$. CTRX in CSF and serum obtained from a patient diagnosed with CIE was measured using the developed HPLCUV system. The concentration of CTRX in CSF and serum was 2.61 and $37.35 \mu \mathrm{g} / \mathrm{mL}$, respectively. We simulated the serum and CSF concentrations of CTRX using simulation software developed by Oda (Figure 1) [18].

Suzuki et al. [19] reported the case of a patient with renal failure who experienced encephalopathy induced by CTRX. An 86-year-old woman undergoing maintenance hemodialysis was treated with CTRX for Helicobacter cinaedi bacteremia, and her mental sta- 
tus worsened during antibiotic administration. During the period when CTRX was administered at $2 \mathrm{~g} /$ day, measured plasma and CSF CTRX concentrations were high $(>100$ and $10.2 \mu \mathrm{g} / \mathrm{mL}$, respectively). The patient reported that mental status improved after the antibiotic treatment was stopped. Table 1 shows the PubMed search results for reports that measured both blood and CSF concentrations of CTRX.

In Japan, the measurement of the CTRX blood concentration is not covered by insurance and is limited to facilities with appropriate laboratory equipment. In practice, there is a time lag between collecting samples and obtaining blood concentration results, making it difficult to use them for differential diagnosis in real time. LC-MS systems can measure blood levels more accurately than HPLC systems but are expensive and therefore impractical. In the future, it would be desirable to have a test system that can be used in general practice so that CTRX blood levels can be measured when AAE is suspected.

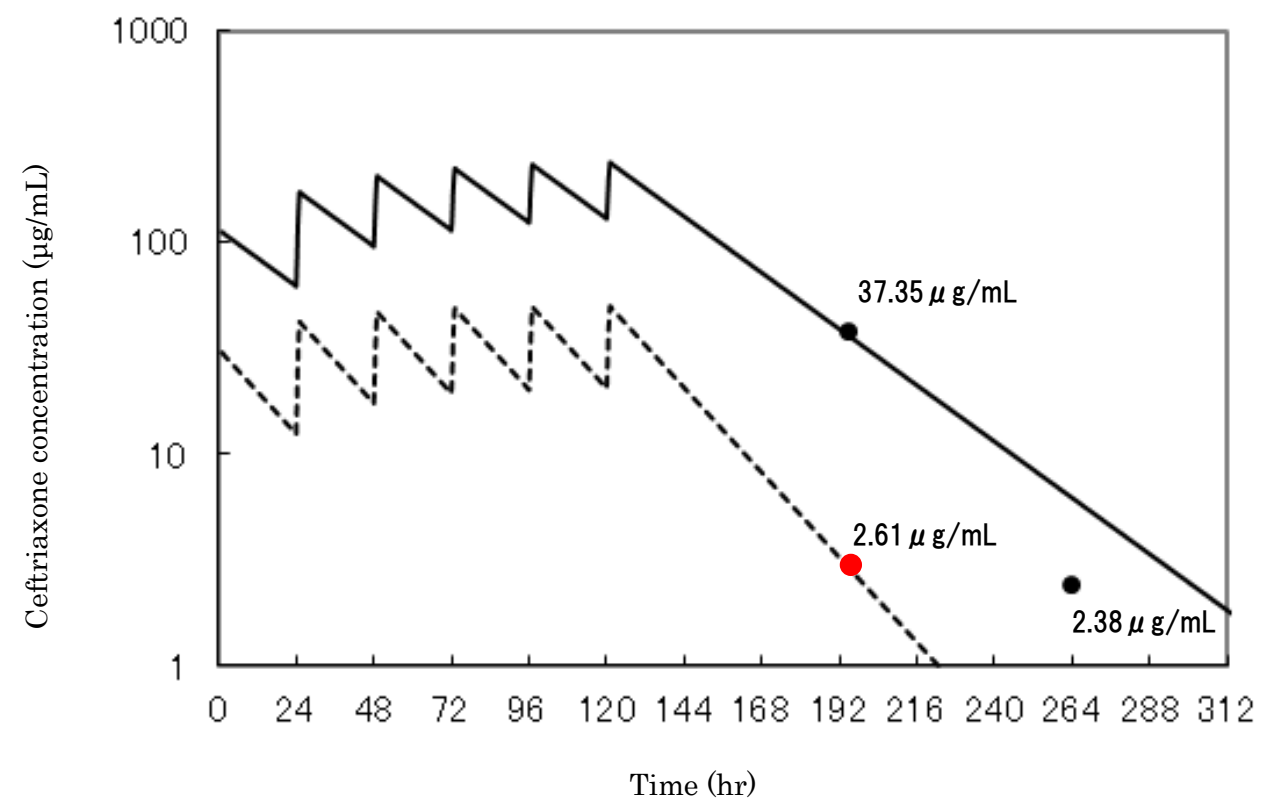

Figure 1. Simulation of blood concentration and human cerebrospinal fluid after ceftriaxone administration [17]. We simulated ourselves using our results. Solid line shows changes in blood concentration after ceftriaxone administration, and dotted line shows changes in cerebrospinal fluid. 
Table 1. Summary of reports that measured both serum and CSF concentrations of CTRX [17,19-22].

\begin{tabular}{|c|c|c|c|c|c|c|c|c|}
\hline Characteristics & Objective & Renal Function & Dose & Measurement system & Measurement accuracy & Blood Concentration & CSF Concentration & Ref \\
\hline $\begin{array}{l}\text { Age: } 75 \\
\text { Sex: female }\end{array}$ & $\begin{array}{l}\text { Development of HPLC method for } \\
\text { accurate, precise, and selective } \\
\text { determination of CTRX and its clinical } \\
\text { application }\end{array}$ & peritoneal dialysis & $2 \mathrm{~g} / \mathrm{day}$ & HPLC-UV & $\begin{array}{l}\text {-Chromatographic peak heights of CTRX: } \\
0.1-100 \text { tg } / \mathrm{mL} \mathrm{r}=0.999) \\
\text {-Detection limit of CTRX: } 35 \mathrm{ng} / \mathrm{mL} \\
\text {-Repeatability }(\mathrm{n}=6) \text { of the } \\
\text { chromatographic peak height for } 4.0 \mu \\
\mathrm{g} / \mathrm{mL} \text { CTRX: } 0.38 \% \mathrm{RSD} \text {. } \\
\text { - Recovery rates of CTRX: }>95.3 \% \text {, and } \\
\text { these RSDs were }<5.8 \%\end{array}$ & $37.35 \mu \mathrm{g} / \mathrm{mL}$ & $2.61 \mu \mathrm{g} / \mathrm{mL}$ & 17 \\
\hline $\begin{array}{c}\text { Age:86 } \\
\text { Sex: female }\end{array}$ & $\begin{array}{l}\text { Report of encephalopathy associated } \\
\text { with high levels of ceftriaxone in plasma } \\
\text { and cerebrospinal fluid, investigation of } \\
\text { the causal relationship between } \\
\text { ceftriaxone administration and the } \\
\text { development of encephalopathy }\end{array}$ & hemodialysis & $2 \mathrm{~g} / \mathrm{day}$ & HPLC & nd & $>100 \mu \mathrm{g} / \mathrm{mL}$ & $10.2 \mu \mathrm{g} / \mathrm{mL}$ & 19 \\
\hline $\begin{array}{l}\text { Population: } \mathrm{n}=43 \text { patients } \\
\text { Sex: male } \\
\text { median age: } 51.7 \text { years (IQR } \\
33.3-67.1) \\
\text { median BMI: } 24.7 \mathrm{~kg} / \mathrm{m}^{2}(\mathrm{IQR} \\
\left.22.4-27.7 \mathrm{~kg} / \mathrm{m}^{2}\right)\end{array}$ & $\begin{array}{l}\text { Determining the role of transporter } \\
\text { genetic variation and blood-brain barrier } \\
\text { permeability in predicting ceftriaxone } \\
\text { exposure in the central nervous system }\end{array}$ & $\begin{array}{l}\text { estimated creatinine } \\
\text { clearance }<30 \mathrm{~mL} / \mathrm{min}\end{array}$ & $2 \mathrm{~g}$ twice a day & HPLC & $\begin{array}{l}\text {-Detection limits: } 0.24 \mathrm{mg} / \mathrm{L} \text { in plasma } \\
\text { and } 0.5 \mathrm{mg} / \mathrm{L} \text { in CSF } \\
\text {-Accuracy: } 5.2 \% \text { for plasma, } 7.2 \% \text { for } \\
\text { CSF } \\
\text {-Intra- and inter-day coefficients of } \\
\text { variation }(\mathrm{CV} \%): 3.6 \% \text { and } 4.5 \% \text { for } \\
\text { plasma samples, and } 7.2 \%, 7.8 \% \text {, and } \\
10.3 \% \text { for CSF samples } \\
\text {-Recovery rate: } 86 \%(\mathrm{CV} \%=3 \text { ) for } \\
\text { CSF samples and } 82 \%(\mathrm{CV} \%=8) \text { for } \\
\text { plasma samples. }\end{array}$ & $\begin{array}{l}\text { Median Cmax: } 157,193.00 \mathrm{ng} / \mathrm{mL} \\
\text { (IQR } 105,164.0-184,852.0 \mathrm{ng} / \mathrm{mL} \text { ) }\end{array}$ & $\begin{array}{l}\text { Median Cmax: } 3512.0 \mathrm{ng} / \mathrm{mL} \\
\text { (IQR } 2134.0-6193.0 \mathrm{ng} / \mathrm{mL})\end{array}$ & 20 \\
\hline Population: $\mathrm{n}=16$ patients & $\begin{array}{l}\text { Evaluation of tolerability and } \\
\text { pharmacokinetic parameters of high- } \\
\text { dose ceftriaxone in adult patients treated } \\
\text { for central nervous system infections: } \\
\text { pharmacological data from two French } \\
\text { cohorts }\end{array}$ & nd & $\begin{array}{l}6.5 \mathrm{~g} / \text { day (range } 4-9 \mathrm{~g} \text { ) } \\
97.5 \mathrm{mg} / \mathrm{kg} \text { (range } 77- \\
131 \mathrm{mg} / \mathrm{kg} \text { ) }\end{array}$ & HPLC & nd & $\begin{array}{l}\text { Median total plasma: } 69.3 \mathrm{mg} / \mathrm{L} \\
\text { (range } 21.6-201.3 \mathrm{mg} / \mathrm{L} ; \mathrm{n}=14 \text { ) } \\
\text { Median unbound plasma: } 7.95 \\
\mathrm{mg} / \mathrm{L}(\text { range } 0.8-43.7 \mathrm{mg} / \mathrm{L} ; \mathrm{n}=8 \text { ) }\end{array}$ & $\begin{array}{l}\text { Median: } 13.3 \mathrm{mg} / \mathrm{L} \text { (range } 0.9- \\
91.2 \mathrm{mg} / \mathrm{L} \text { ) }\end{array}$ & 21 \\
\hline Population: $\mathrm{n}=7$ patients & $\begin{array}{l}\text { Investigation of the pharmacokinetics of } \\
\text { both antibiotics in patients with non- } \\
\text { inflammatory obstructive hydrocephalus } \\
\text { undergoing external ventricular surgery } \\
\text { treated with cefotaxime or ceftriaxone } \\
\text { for extracerebral infections }\end{array}$ & $\mathrm{Scr}<1.5 \mathrm{mg} / \mathrm{dL}$ & $\begin{array}{l}2 \mathrm{~g} \text { single dose } \\
30 \mathrm{~min}\end{array}$ & HPLC-UV & $\begin{array}{l}\text {-Quantification limits of ceftriaxone; } \\
0.8 \mathrm{mg} / \mathrm{L} \text { in serum and } 0.08 \mathrm{mg} / \mathrm{L} \text { in } \\
\text { CSF. } \\
\text {-Interday coefficients of variation; } 2.0 \% \\
\text { at } 99.7 \text { and } 6.8 \% \text { at } 1.55 \mathrm{mg} / \mathrm{L} \text { in } \\
\text { serum and } 3.3 \% \text { at } 16.2 \text { and } 6.4 \% \text { at } \\
0.16 \mathrm{mg} / \mathrm{L} \text { in } \mathrm{CSF}(\mathrm{n}=6) \text {. }\end{array}$ & $\begin{array}{l}\text { Cmax: } 172.2-271.7 \mathrm{mg} / \mathrm{L}(\text { median }= \\
249.6 ; \mathrm{n}=6)\end{array}$ & $\begin{array}{l}\text { Cmax: } 0.18-1.04 \mathrm{mg} / \mathrm{L}(\text { median } \\
=0.43 ; \mathrm{n}=5) \text {, confirmed } 1-16 \\
\mathrm{~h} \text { after injection (median }=12 \\
\mathrm{~h} ; \mathrm{n}=5 \text { ). }\end{array}$ & 22 \\
\hline
\end{tabular}

HPLC:high performance liquid chromatography; HPLC-UV:high performance liquid chromatography with ultraviolet detection ; Scr: serum creatinine; CSF: cerebrospinal fluid; IQR:interquartile range ; RSD: relative standard deviation; nd: not described

\section{TDM of Daptomycin}

\subsection{Characteristics of Daptomycin and Significance of Blood Level Measurement}

Daptomycin (DAP) is a lipopeptide antibiotic that is effective against antibiotic-resistant Gram-positive bacteria such as methicillin-resistant Staphylococcus aureus (MRSA) and vancomycin-resistant enterococci (VRE) $[23,24]$. DAP has a molecular weight of about $1.6 \mathrm{kDa}$, a high protein-binding rate (90-95\%), and a distribution volume of $0.1 \mathrm{~L} / \mathrm{kg}$ [21]. The elimination half-life of DAP is approximately 8 to $9 \mathrm{~h}$ in adults [25]. Currently, TDM of DAP is not routinely performed in clinical practice in Japan. A once-daily dose of 4 $\mathrm{mg} / \mathrm{kg}$ is administered for skin and soft tissue infections and $6 \mathrm{mg} / \mathrm{kg}$ for sepsis and infective endocarditis of the right heart system [26]. DAP has also been administered every 48 $\mathrm{h}$ in patients whose creatinine clearance (CLcr) is less than $30 \mathrm{~mL} / \mathrm{min}$ or who require dialysis [27]. Since this drug is mainly excreted by the kidneys, the dosage should be adjusted for patients with impaired renal function.

It has been reported that the efficacy of DAP is strongly correlated with the areaunder-the-curve/minimum inhibitory concentration (AUC/MIC) ratio and peak concentration/MIC (Cpeak/MIC) ratio [28] and is considered to be drug concentration dependent. In clinical studies, an AUC/MIC of 666 or higher in MRSA infections was associated with lower mortality [29], and a trough concentration of less than $3.18 \mathrm{mg} / \mathrm{L}$ (steady state) was associated with poorer clinical outcomes [30]. A typical side effect of DAP is increased creatine phosphokinase (CPK) levels [31,32]. In particular, it is known that a blood level of $24.3 \mathrm{mg} / \mathrm{L}$ or higher increases the risk of higher CPK levels [31]. On the other hand, safety and tolerability at high doses ( $\geq 8 \mathrm{mg} / \mathrm{kg}$ ) have also been reported [33-35], and the correlation between elevated CPK levels and dosage and blood levels is not clear. Blood levels of DAP vary widely from patient to patient, and factors that may contribute to this variability include renal function, hemodialysis, continuous renal replacement therapy, obesity, hypoalbuminemia, and the pathogenesis of severe infections [30,36-39]. At this stage, there is insufficient evidence to conclusively determine a correlation between the 
efficacy and adverse effects of DAP and blood levels of the drug, and it is unclear whether TDM of DAP should be recommended for clinical practice in Japan.

\subsection{Report on the Measurement of Blood Levels of Daptomycin in Japan}

We present a report on the measurement of blood levels of DAP in clinical practice in Japan and its application to the treatment of infectious diseases.

Urakami et al. [40] used Monte Carlo simulation and TDM to investigate the best way to manage DAP based on PK/PD parameters. Serum concentrations of DAP in 16 MRSAinfected patients were measured by the HPLC-UV system. First, venous blood ( $5 \mathrm{~mL}$ ) was collected, and the blood sample was centrifuged at $5000 \times \mathrm{g}$ for $10 \mathrm{~min}$ and stored at -30 ${ }^{\circ} \mathrm{C}$ until plasma analysis. The lower limit of quantification for this assay was $0.78 \mu \mathrm{g} / \mathrm{mL}$. The analysis column was a TSK gel Octyl -80 Ts, $5 \mu, 250 \times 4.6 \mathrm{~mm}$ (TOSOH, Tokyo, Japan), UV wavelength was $214 \mathrm{~nm}$, mobile phase was $40 \mathrm{mM}$ phosphate ammonium buffer $(\mathrm{pH} 4.5) /$ acetonitrile $=60: 40 \mathrm{v} / v$. All used solvents were HPLC grade [40]

As a DAP pharmacokinetics parameter, the volume of distribution of patients in the study was larger than the volume of distribution among healthy Japanese subjects. The half-life of this drug is 8.9 to $34.9 \mathrm{~h}$, which gradually increased as CLcr decreased. In the Monte Carlo simulation, the cumulative fraction of response (CFR) for Cpeak/MIC $\geq 60$ [28] and AUC/MIC $\geq 666$ at $6 \mathrm{mg} / \mathrm{kg}$ every $24 \mathrm{~h}$ was $72.0 \%$ and $78.8 \%$, respectively, whereas at $10 \mathrm{mg} / \mathrm{kg}$ every $24 \mathrm{~h}$ both CFR values improved to $99 \%$. With TDM of DAP at $6 \mathrm{mg} / \mathrm{kg}$ every $24 \mathrm{~h}$, the target peak and AUC were reached in $40 \%$ of patients ( 2 of 5 ). In that study, they reported that TDM is necessary because of individual differences in PK with DAP. A high-dose regimen of $8 \mathrm{mg} / \mathrm{kg}$ or higher may be required to ensure efficacy, especially in Japanese patients with normal renal function. In this study, one patient with a trough level of $49.4 \mu \mathrm{g} / \mathrm{mL}$ and CLcr of $22.4 \mathrm{~mL} / \mathrm{min}$ had elevated CPK, but no other patients had adverse events attributable to DAP.

Yamada et al. [41] investigated the relationship between DAP trough concentration (Cmin) and CPK elevation to determine the optimal DAP administration. DAP concentrations in the plasma of 20 patients were measured. Plasma samples were collected at trough and Cpeak within 60 min after the end of infusion on day 3 after DAP administration. HPLC analysis was coupled with use of a UV detector set to a detection wavelength of $214 \mathrm{~nm}$. The column used was an Octyl 80Ts $(4.6250 \mathrm{~mm})$ and the temperature was set at $37^{\circ} \mathrm{C}$. Acetonitrile and ammonium phosphate buffer $(40 \mathrm{mM}, \mathrm{pH} 4)$ (40:60) were used in the mobile phase, and the flow rate was $1.5 \mathrm{~mL} / \mathrm{min}$.. The lower limit of quantification for HPLC was $1.0 \mu \mathrm{g} / \mathrm{mL}$, and the intra- and interday coefficients of variation were less than $5.0 \%$. Logistic regression analysis was performed, and Cmin of DAP was significantly associated with elevated CPK and was concentration dependent (odds ratio 1.21, $p$ $=0.048$ ). Patients with DAP Cmin $<19.5 \mu \mathrm{g} / \mathrm{mL}$ did not show increased CPK, but those with Cmin $>19.5 \mu \mathrm{g} / \mathrm{mL}$ had a high rate of increased CPK $(4 / 5,80 \%)$, and three of these patients showed increased CPK after one week of treatment. Based on the results of the Monte Carlo simulation to determine the optimal dose of DAP, the estimated doses were $4-6 \mathrm{mg} / \mathrm{kg} /$ day when the MIC was $0.5 \mu \mathrm{g} / \mathrm{mL}$ or less and $10 \mathrm{mg} / \mathrm{kg} /$ day when the MIC was $1 \mu \mathrm{g} / \mathrm{mL}$.

In addition to the above reports, the use of liquid chromatography-tandem mass spectrometry (LC-MS/MS) [42], ultra-performance liquid chromatography coupled to tandem mass spectrometry (UPLC-MS/MS) [43], and HPLC equipped with a photodiode array (UHPLC-PDA) [44] was also studied.

\section{TDM of Linezolid}

\subsection{Characteristics of Linezolid and Significance of Blood Level Measurement}

Linezolid (LZD) is an oxazolidinone drug that has excellent antibacterial activity against Gram-positive bacteria, including MRSA and VRE $[45,46]$. The plasma proteinbinding rate and volume of LZD distribution in adults are 31\% and 40-50 L, respectively [47]. Myelosuppression, including anemia and thrombocytopenia, has been reported as a serious side effect of LZD and is generally reversible when discontinuing treatment, with 
recovery usually taking 1-2 weeks [48]. LZD does not require dosage adjustment with or without renal dysfunction [49,50]. The PK/PD parameter is the percentage of time that plasma concentration exceeds the MIC ( $\% \mathrm{~T}>\mathrm{MIC}$ ) by greater than $85 \%$, and the AUC/MIC ratio is $80-120$ [51,52]. In terms of thrombocytopenia, the recommended range of trough concentrations for DAP is $2.0-7.0 \mathrm{mg} / \mathrm{L}$ [53]. Patients with impaired renal function may have significantly lower platelet counts than those with normal renal function, and there are reports of therapeutic outcomes with TDM of LZD [54-56].

\subsection{Report on the Measurement of Blood Levels of Linezolid in Japan}

There are case reports of successful treatment of infection when Japanese hospital pharmacists performed TDM of LZD.

Tsuji et al. [57] investigated mediastinitis after cardiac surgery that was caused by MRSA in patients with renal dysfunction by measuring trough concentrations in serum and wound exudate to adjust the LZD dose. They reported that there was little decrease in efficacy with the change in dosage and it prevented worsening thrombocytopenia. Matsuda et al. [58] reported on trough concentrations measured early after LZD administration for wound infections caused by MRSA, and long-term administration for 28 days was tolerated. Ashizawa et al. [59] performed TDM of LZD for patients treated with a combination of LZD and rifampicin (RFP) for osteomyelitis caused by MRSA. The concomitant use of LZD and RFP may decrease the serum concentration of linezolid due to drug interactions, which may reduce the therapeutic effect [53]. They reported that LZD was effective in monitoring trough concentrations without reducing the dose.

\section{Conclusions}

This paper discusses the need for TDM of antimicrobials for which TDM cannot be billed to insurance in Japan, and the reporting of facilities that implement it. In order to build evidence supporting the use of TDM, it is necessary to establish methods for measuring drugs, introduce analytical equipment, and enhance medical staff with expertise. It is desirable to establish a system in which pharmaceutical universities and medical institutions, which are well equipped with these facilities, work together to build evidence for recommending TDM.

Author Contributions: Conceptualization, F.E.; writing-original draft preparation, F.E., Y.H., T.M., and T.K.; writing - review and editing, F.E., Y.H., T.M., and T.K. All authors have read and agreed to the published version of the manuscript.

Funding: This research received no external funding.

Institutional Review Board Statement: Not applicable.

Informed Consent Statement: Not applicable.

Data Availability Statement: All data are applicable in the paper.

Conflicts of Interest: The authors declare no conflicts of interest.

\section{References}

1. Morikawa, G.; Sorimachi, M.; Tamura, K.; Moriiwa, Y.; Shoji, A.; Okazawa, K.; Yanagida, A. Development of a practical HPLC system for in-hospital analysis of blood concentration of various medicines. Bunseki Kagaku 2019, 68, 473-481.

2. Saito, T.; Tominaga, A.; Nozawa, M.; Unei, H.; Hatano, Y.; Fujita, Y.; Iseki, K.; Hori, Y. Committee on Toxicology Laboratories; Japanese Society for Clinical Toxicology [Survey of analytical works for drugs at emergency and critical care centers with highperformance instruments provided by the Ministry of Health and Welfare (at present: Ministry of Health, Labour, and Welfare) in fiscal 1998--continuation of survey with 2008 survey results as point of reference]. Chudoku Kenkyu 2013, 26, 226-233.

3. Otani, N.; Hifumi, T.; Kitamoto, T.; Kobayashi, K.; Nakaya, N.; Tomioka, J. Current State of Drug Analysis in Japanese Emergency Departments: A Nationwide Survey. Acute Med. Surg. 2020, 7, e566. https://doi.org/10.1002/ams2.566.

4. Klein, N.C.; Cunha, B.A. Third-Generation Cephalosporins. Med. Clin. North Am. 1995, 79, 705-719. https://doi.org/10.1016/s0025-7125(16)30034-7.

5. Aronoff, G.R.; Bennett, W.M.; Berns, J.S.; Brier, M.E.; Kasbekar, N.; Mueller, B.A.; Pasko, D.A.; Smoyer, W.E. Drug Prescribing in Renal Failure: Dosing Guidelines for Adults and Children, 5th ed.; American College of Physicians: Philadelphia, PA, USA, 2007; p. 153. 
6. Patel, I.H.; Sugihara, J.G.; Weinfeld, R.E.; Wong, E.G.; Siemsen, A.W.; Berman, S.J. Ceftriaxone Pharmacokinetics in Patients with Various Degrees of Renal Impairment. Antimicrob. Agents Chemother. 1984, 25, 438-442. https://doi.org/10.1128/AAC.25.4.438.

7. Bhattacharyya, S.; Darby, R.R.; Raibagkar, P.; Gonzalez Castro, L.N.; Berkowitz, A.L. Antibiotic-Associated Encephalopathy. Neurology 2016, 86, 963-971. https://doi.org/10.1212/WNL.0000000000002455.

8. Lamoth, F.; Buclin, T.; Pascual, A.; Vora, S.; Bolay, S.; Decosterd, L.A.; Calandra, T.; Marchetti, O. High Cefepime Plasma Concentrations and Neurological Toxicity in Febrile Neutropenic Patients with Mild Impairment of Renal Function. Antimicrob. Agents Chemother. 2010, 54, 4360-4367. https://doi.org/10.1128/AAC.01595-08.

9. Durand-Maugard, C.; Lemaire-Hurtel, A.-S.; Gras-Champel, V.; Hary, L.; Maizel, J.; Prud’homme-Bernardy, A.; Andréjak, C.; Andréjak, M. Blood and CSF Monitoring of Cefepime-Induced Neurotoxicity: Nine Case Reports. J. Antimicrob. Chemother. 2012, 67, 1297-1299. https://doi.org/10.1093/jac/dks012.

10. Rhodes, N.J.; Kuti, J.L.; Nicolau, D.P.; Neely, M.N.; Nicasio, A.M.; Scheetz, M.H. An Exploratory Analysis of the Ability of a Cefepime Trough Concentration Greater than $22 \mathrm{Mg} / \mathrm{L}$ to Predict Neurotoxicity. J. Infect. Chemother. 2016, 22 , 78-83. https://doi.org/10.1016/j.jiac.2015.10.009.

11. Lacroix, C.; Kheloufi, F.; Montastruc, F.; Bennis, Y.; Pizzoglio, V.; Micallef, J. Serious Central Nervous System Side Effects of Cephalosporins: A National Analysis of Serious Reports Registered in the French Pharmacovigilance Database. J. Neurol. Sci. 2019, 398, 196-201. https://doi.org/10.1016/j.jns.2019.01.018.

12. Kim, K.B.; Kim, S.M.; Park, W.; Kim, J.S.; Kwon, S.K.; Kim, H.-Y. Ceftiaxone-Induced Neurotoxicity: Case Report, Pharmacokinetic Considerations, and Literature Review. J. Korean Med. Sci. 2012, 27, 1120-1123. https://doi.org/10.3346/jkms.2012.27.9.1120.

13. Yokoyama, Y.; Hosokawa, N.; Kudo, T.; Goda, H.; Ito, K.; Suzuki, M.; Funakoshi, R. Chorea-like Symptoms and High Blood Concentration of Ceftriaxone in a Patient Undergoing Hemodialysis: A Case Report. J. Infect. Chemother. 2020, 26, 285-288. https://doi.org/10.1016/j.jiac.2019.10.005.

14. Inoue, Y.; Doi, Y.; Arisato, T.; Sugioka, S.; Koga, K.; Nishioka, K.; Sugawara, A. Three Cases of Hemodialysis Patients Receiving High-Dose Ceftriaxone: Serum Concentrations and Its Neurotoxicity. Kidney Int. Rep. 2017, 2, $984-987$. https://doi.org/10.1016/j.ekir.2017.03.009.

15. Lacroix, C.; Bera-Jonville, A.-P.; Montastruc, F.; Velly, L.; Micallef, J.; Guilhaumou, R. Serious Neurological Adverse Events of Ceftriaxone. Antibiotics (Basel) 2021, 10, 540. https://doi.org/10.3390/antibiotics10050540.

16. AMR Clinical Reference Center. Surveillance of Antibiotic Sales in Japan. Available online: https://amrcrc.ncgm.go.jp/surveillance/020/salestableDDD2017_2021.4.xlsx (accessed on 18 December 2021).

17. Kotani, A.; Hirai, J.; Hamada, Y.; Fujita, J.; Hakamata, H. Determination of Ceftriaxone Concentration in Human Cerebrospinal Fluid by High-Performance Liquid Chromatography with UV Detection. J. Chromatogr. B Analyt. Technol. Biomed. Life Sci. 2019, 1124, 161-164. https://doi.org/10.1016/j.jchromb.2019.06.008.

18. Oda, K. Development of Software for Antimicrobial PK/PD Simulation Incorporating Montecarlo Simulation Based on Microsoft^ $\left.\right|^{\wedge}$ reg; Office Excel. Iryo Yakugaku (Jpn. J. Pharm. Health Care Sci.) 2011, 37, 335-344. https://doi.org/10.5649/jjphcs.37.335.

19. Suzuki, S.; Naito, S.; Numasawa, Y.; Asada, M.; Shoji, N.; Zeniya, M.; Takahashi, D.; Sato, H.; Iimori, S.; Nomura, N.; et al. Encephalopathy Induced by High Plasma and Cerebrospinal Fluid Ceftriaxone Concentrations in a Hemodialysis Patient. Intern. Med. 2019, 58, 1775-1779. https://doi.org/10.2169/internalmedicine.1785-18.

20. Allegra, S.; Cardellino, C.S.; Fatiguso, G.; Cusato, J.; De Nicolò, A.; Avataneo, V.; Bonora, S.; D' Avolio, A.; Di Perri, G.; Calcagno, A. Effect of ABCC2 and ABCG2 Gene Polymorphisms and CSF-to-Serum Albumin Ratio on Ceftriaxone Plasma and Cerebrospinal Fluid Concentrations. J. Clin. Pharmacol. 2018, 58, 1550-1556. https://doi.org/10.1002/jcph.1266.

21. Le Turnier, P.; Grégoire, M.; Garot, D.; Guimard, T.; Duval, X.; Bernard, L.; Boutoille, D.; Dailly, É.; Navas, D.; Asseray, N. CSF Concentration of Ceftriaxone Following High-Dose Administration: Pharmacological Data from Two French Cohorts. J. Antimicrob. Chemother. 2019, 74, 1753-1755. https://doi.org/10.1093/jac/dkz047.

22. Nau, R.; Prange, H.W.; Muth, P.; Mahr, G.; Menck, S.; Kolenda, H.; Sörgel, F. Passage of Cefotaxime and Ceftriaxone into Cerebrospinal Fluid of Patients with Uninflamed Meninges. Antimicrob. Agents Chemother. 1993, 37, 1518-1524.

23. Wootton, M.; MacGowan, A.P.; Walsh, T.R. Comparative Bactericidal Activities of Daptomycin and Vancomycin against Glycopeptide-Intermediate Staphylococcus Aureus (GISA) and Heterogeneous GISA Isolates. Antimicrob. Agents Chemother. 2006, 50, 4195-4197. https://doi.org/10.1128/AAC.00678-06.

24. Dandekar, P.K.; Tessier, P.R.; Williams, P.; Nightingale, C.H.; Nicolau, D.P. Pharmacodynamic Profile of Daptomycin against Enterococcus Species and Methicillin-Resistant Staphylococcus Aureus in a Murine Thigh Infection Model. J. Antimicrob. Chemother. 2003, 52, 405-411. https://doi.org/10.1093/jac/dkg337.

25. Dvorchik, B.H.; Brazier, D.; DeBruin, M.F.; Arbeit, R.D. Daptomycin Pharmacokinetics and Safety Following Administration of Escalating Doses Once Daily to Healthy Subjects. Antimicrob. Agents Chemother. 2003, 47, $1318-1323$. https://doi.org/10.1128/AAC.47.4.1318-1323.2003.

26. Cubist Pharmaceuticals. Cubicin Package Insert; Cubist Pharmaceuticals: Lexington, MA, USA, 2003.

27. Hawkey, P.M. Pre-Clinical Experience with Daptomycin. J. Antimicrob. Chemother. 2008, 62 (Suppl. 3), iii7-14. https://doi.org/10.1093/jac/dkn367.

28. Safdar, N.; Andes, D.; Craig, W.A. In Vivo Pharmacodynamic Activity of Daptomycin. Antimicrob. Agents Chemother. 2004, 48, 63-68. https://doi.org/10.1128/AAC.48.1.63-68.2004.

29. Falcone, M.; Russo, A.; Cassetta, M.I.; Lappa, A.; Tritapepe, L.; d'Ettorre, G.; Fallani, S.; Novelli, A.; Venditti, M. Variability of Pharmacokinetic Parameters in Patients Receiving Different Dosages of Daptomycin: Is Therapeutic Drug Monitoring Necessary? J. Infect. Chemother. 2013, 19, 732-739. https://doi.org/10.1007/s10156-013-0559-z. 
30. Galar, A.; Muñoz, P.; Valerio, M.; Cercenado, E.; García-González, X.; Burillo, A.; Sánchez-Somolinos, M.; Juárez, M.; Verde, E.; Bouza, E. Current Use of Daptomycin and Systematic Therapeutic Drug Monitoring: Clinical Experience in a Tertiary Care Institution. Int. J. Antimicrob. Agents 2019, 53, 40-48. https://doi.org/10.1016/j.ijantimicag.2018.09.015.

31. Bhavnani, S.M.; Rubino, C.M.; Ambrose, P.G.; Drusano, G.L. Daptomycin Exposure and the Probability of Elevations in the Creatine Phosphokinase Level: Data from a Randomized Trial of Patients with Bacteremia and Endocarditis. Clin. Infect. Dis. 2010, 50, 1568-1574. https://doi.org/10.1086/652767.

32. Kazory, A.; Dibadj, K.; Weiner, I.D. Rhabdomyolysis and Acute Renal Failure in a Patient Treated with Daptomycin. J. Antimicrob. Chemother. 2006, 57, 578-579. https://doi.org/10.1093/jac/dki476.

33. Cojutti, P.G.; Candoni, A.; Ramos-Martin, V.; Lazzarotto, D.; Zannier, M.E.; Fanin, R.; Hope, W.; Pea, F. Population Pharmacokinetics and Dosing Considerations for the Use of Daptomycin in Adult Patients with Haematological Malignancies. J. Antimicrob. Chemother. 2017, 72, 2342-2350. https://doi.org/10.1093/jac/dkx140.

34. Carugati, M.; Bayer, A.S.; Miró, J.M.; Park, L.P.; Guimarães, A.C.; Skoutelis, A.; Fortes, C.Q.; Durante-Mangoni, E.; Hannan, M.M.; Nacinovich, F.; et al. High-Dose Daptomycin Therapy for Left-Sided Infective Endocarditis: A Prospective Study from the International Collaboration on Endocarditis. Antimicrob. Agents Chemother. 2013, 57, 6213-6222. https://doi.org/10.1128/AAC.01563-13.

35. Seaton, R.A.; Menichetti, F.; Dalekos, G.; Beiras-Fernandez, A.; Nacinovich, F.; Pathan, R.; Hamed, K. Evaluation of Effectiveness and Safety of High-Dose Daptomycin: Results from Patients Included in the European Cubicin $\left({ }^{\circledR}\right)$ Outcomes Registry and Experience. Adv. Ther. 2015, 32, 1192-1205. https://doi.org/10.1007/s12325-015-0267-4.

36. Reiber, C.; Senn, O.; Müller, D.; Kullak-Ublick, G.A.; Corti, N. Therapeutic Drug Monitoring of Daptomycin: A Retrospective Monocentric Analysis. Ther. Drug Monit. 2015, 37, 634-640. https://doi.org/10.1097/FTD.0000000000000196.

37. Di Paolo, A.; Tascini, C.; Polillo, M.; Gemignani, G.; Nielsen, E.I.; Bocci, G.; Karlsson, M.O.; Menichetti, F.; Danesi, R. Population Pharmacokinetics of Daptomycin in Patients Affected by Severe Gram-Positive Infections. Int. J. Antimicrob. Agents 2013, 42, 250-255. https://doi.org/10.1016/j.ijantimicag.2013.06.006.

38. Goutelle, S.; Roux, S.; Gagnieu, M.-C.; Valour, F.; Lustig, S.; Ader, F.; Laurent, F.; Chidiac, C.; Ferry, T. Pharmacokinetic Variability of Daptomycin during Prolonged Therapy for Bone and Joint Infections. Antimicrob. Agents Chemother. 2016, 60, 31483151. https://doi.org/10.1128/AAC.02597-15.

39. Barreau, S.; Benaboud, S.; Kernéis, S.; Moachon, L.; Blanche, P.; Groh, M.; Massias, L.; Treluyer, J.-M.; Poyart, C.; Raymond, J. Staphylococcus Aureus Osteo-Articular Infection: Usefulness of the Determination of Daptomycin Serum Concentration to Explain a Treatment Failure. Int. J. Clin. Pharmacol. Ther. 2016, 54, 923-927. https://doi.org/10.5414/CP202538.

40. Urakami, T.; Hamada, Y.; Oka, Y.; Okinaka, T.; Yamakuchi, H.; Magarifuchi, H.; Aoki, Y. Clinical Pharmacokinetic and Pharmacodynamic Analysis of Daptomycin and the Necessity of High-Dose Regimen in Japanese Adult Patients. J. Infect. Chemother. 2019, 25, 437-443. https://doi.org/10.1016/j.jiac.2019.01.011.

41. Yamada, T.; Ooi, Y.; Oda, K.; Shibata, Y.; Kawanishi, F.; Suzuki, K.; Nishihara, M.; Nakano, T.; Yoshida, M.; Uchida, T.; et al. Observational Study to Determine the Optimal Dose of Daptomycin Based on Pharmacokinetic/Pharmacodynamic Analysis. J. Infect. Chemother. 2020, 26, 379-384. https://doi.org/10.1016/j.jiac.2019.11.002.

42. Miyadera, Y.; Naito, T.; Yamada, T.; Kawakami, J. Simple LC-MS/MS Methods Using Core-Shell Octadecylsilyl Microparticulate for the Quantitation of Total and Free Daptomycin in Human Plasma. Ther. Drug Monit. 2018, 40, 589-595. https://doi.org/10.1097/FTD.0000000000000535.

43. Tanaka, R.; Suzuki, Y.; Goto, K.; Yasuda, N.; Koga, H.; Kai, S.; Ohchi, Y.; Sato, Y.; Kitano, T.; Itoh, H. Development and Validation of Sensitive and Selective Quantification of Total and Free Daptomycin in Human Plasma Using Ultra-Performance Liquid Chromatography Coupled to Tandem Mass Spectrometry. J. Pharm. Biomed. Anal. 2019, 165, 56-64. https://doi.org/10.1016/j.jpba.2018.11.047.

44. Ando, M.; Nishioka, H.; Nakasako, S.; Kuramoto, E.; Ikemura, M.; Kamei, H.; Sono, Y.; Sugioka, N.; Fukushima, S.; Hashida, T. Observational Retrospective Single-Centre Study in Japan to Assess the Clinical Significance of Serum Daptomycin Levels in Creatinine Phosphokinase Elevation. J. Clin. Pharm. Ther. 2020, 45, 290-297. https://doi.org/10.1111/jcpt.13061.

45. Bozdogan, B.; Appelbaum, P.C. Oxazolidinones: Activity, Mode of Action, and Mechanism of Resistance. Int. J. Antimicrob. Agents 2004, 23, 113-119. https://doi.org/10.1016/j.ijantimicag.2003.11.003.

46. Mendes, R.E.; Deshpande, L.M.; Jones, R.N. Linezolid Update: Stable in Vitro Activity Following More than a Decade of Clinical Use and Summary of Associated Resistance Mechanisms. Drug Resist. Updates 2014, 17, 1-12. https://doi.org/10.1016/j.drup.2014.04.002.

47. Bassetti, M.; Baguneid, M.; Bouza, E.; Dryden, M.; Nathwani, D.; Wilcox, M. European Perspective and Update on the Management of Complicated Skin and Soft Tissue Infections Due to Methicillin-Resistant Staphylococcus Aureus after More than 10 Years of Experience with Linezolid. Clin. Microbiol. Infect. 2014, 20 (Suppl. 4), 3-18. https://doi.org/10.1111/1469-0691.12463.

48. Gerson, S.L.; Kaplan, S.L.; Bruss, J.B.; Le, V.; Arellano, F.M.; Hafkin, B.; Kuter, D.J. Hematologic Effects of Linezolid: Summary of Clinical Experience. Antimicrob. Agents Chemother. 2002, 46, 2723-2726. https://doi.org/10.1128/AAC.46.8.2723-2726.2002.

49. Brier, M.E.; Stalker, D.J.; Aronoff, G.R.; Batts, D.H.; Ryan, K.K.; O'Grady, M.; Hopkins, N.K.; Jungbluth, G.L. Pharmacokinetics of Linezolid in Subjects with Renal Dysfunction. Antimicrob. Agents Chemother. 2003, 47, $2775-2780$. https://doi.org/10.1128/AAC.47.9.2775-2780.2003.

50. Cattaneo, D.; Gervasoni, C.; Cozzi, V.; Castoldi, S.; Baldelli, S.; Clementi, E. Therapeutic Drug Management of Linezolid: A Missed Opportunity for Clinicians? Int. J. Antimicrob. Agents 2016, 48, 728-731. https://doi.org/10.1016/j.ijantimicag.2016.08.023. 
51. Rayner, C.R.; Forrest, A.; Meagher, A.K.; Birmingham, M.C.; Schentag, J.J. Clinical Pharmacodynamics of Linezolid in Seriously Ill Patients Treated in a Compassionate Use Programme. Clin. Pharmacokinet. 2003, 42, 1411-1423. https://doi.org/10.2165/00003088-200342150-00007.

52. Abdul-Aziz, M.H.; Alffenaar, J.-W.C.; Bassetti, M.; Bracht, H.; Dimopoulos, G.; Marriott, D.; Neely, M.N.; Paiva, J.-A.; Pea, F.; Sjovall, F.; et al. Antimicrobial Therapeutic Drug Monitoring in Critically Ill Adult Patients: A Position Paper. Intensive Care Med. 2020, 46, 1127-1153. https://doi.org/10.1007/s00134-020-06050-1.

53. Pea, F.; Viale, P.; Cojutti, P.; Del Pin, B.; Zamparini, E.; Furlanut, M. Therapeutic Drug Monitoring May Improve Safety Outcomes of Long-Term Treatment with Linezolid in Adult Patients. J. Antimicrob. Chemother. 2012, 67, $2034-2042$. https://doi.org/10.1093/jac/dks153.

54. Matsumoto, K.; Takeshita, A.; Ikawa, K.; Shigemi, A.; Yaji, K.; Shimodozono, Y.; Morikawa, N.; Takeda, Y.; Yamada, K. Higher Linezolid Exposure and Higher Frequency of Thrombocytopenia in Patients with Renal Dysfunction. Int. J. Antimicrob. Agents 2010, 36, 179-181. https://doi.org/10.1016/j.ijantimicag.2010.02.019.

55. Nukui, Y.; Hatakeyama, S.; Okamoto, K.; Yamamoto, T.; Hisaka, A.; Suzuki, H.; Yata, N.; Yotsuyanagi, H.; Moriya, K. High Plasma Linezolid Concentration and Impaired Renal Function Affect Development of Linezolid-Induced Thrombocytopenia. J. Antimicrob. Chemother. 2013, 68, 2128-2133. https://doi.org/10.1093/jac/dkt133.

56. Tsuji, Y.; Holford, N.H.G.; Kasai, H.; Ogami, C.; Heo, Y.-A.; Higashi, Y.; Mizoguchi, A.; To, H.; Yamamoto, Y. Population Pharmacokinetics and Pharmacodynamics of Linezolid-Induced Thrombocytopenia in Hospitalized Patients. Br. J. Clin. Pharmacol. 2017, 83, 1758-1772. https://doi.org/10.1111/bcp.13262.

57. Tsuji, Y.; Tashiro, M.; Ashizawa, N.; Ota, Y.; Obi, H.; Nagura, S.; Narukawa, M.; Fukahara, K.; Yoshimura, N.; To, H.; et al. Treatment of Mediastinitis Due to Methicillin-Resistant Staphylococcus Aureus in a Renal Dysfunction Patient Undergoing Adjustments to the Linezolid Dose. Intern. Med. 2015, 54, 235-239. https://doi.org/10.2169/internalmedicine.54.2292.

58. Matsuda, S.; Kimura, R.; Izumi, K.; Noguchi, A.; Imazu, T.; Kugaya, Y.; Shimokawa, F.; Maeda, Y. Two Cases for Prevention of Linezolid-Induced Thrombocytopenia by Therapeutic Drug Monitoring. J. Jpn. Soc. Hosp. Pharm. 2019, 55, $423-427$.

59. Ashizawa, N.; Tsuji, Y.; Kawago, K.; Higashi, Y.; Tashiro, M.; Nogami, M.; Gejo, R.; Narukawa, M.; Kimura, T.; Yamamoto, Y. Successful Treatment of Methicillin-Resistant Staphylococcus Aureus Osteomyelitis with Combination Therapy Using Linezolid and Rifampicin under Therapeutic Drug Monitoring. J. Infect. Chemother. 2016, 22, 331-334. https://doi.org/10.1016/j.jiac.2015.11.012. 